Article

\title{
Landsat-TM-Based Discrimination of Lithological Units Associated with the Purtuniq Ophiolite, Quebec, Canada
}

\author{
David W. Leverington ${ }^{1, *}$ and Wooil M. Moon ${ }^{2}$ \\ 1 Department of Geosciences, Texas Tech University, Lubbock, TX 79401, USA \\ 2 Department of Geological Sciences, University of Manitoba, Winnipeg, MB R3T 2N2, Canada; \\ E-Mail:wmoon@cc.umanitoba.ca \\ * Author to whom correspondence should be addressed; E-Mail: david.leverington@ttu.edu; \\ Tel.: +1-806-742-1603; Fax: +1-806-742-0100.
}

Received: 16 March 2012; in revised form: 26 April 2012 / Accepted: 26 April 2012 /

Published: 4 May 2012

\begin{abstract}
In order to better constrain the utility of multispectral datasets in the characterization of surface materials, Landsat Thematic Mapper (TM) data were evaluated in the discrimination of geological classes in the Cape Smith Belt of Quebec, a greenstone belt that hosts Early Proterozoic units including those of the Purtuniq ophiolite. Ground-based measurements collected for the study area highlight the importance of chemical alteration in controlling the reflectance properties of key geological classes. The spatial distribution of exposed lithologies in the study area was determined through (1) image classification using a feedforward backpropagation neural network classifier; and (2) generation of fraction images for spectral end members using a linear unmixing algorithm and ground reflectance data. Despite some shortcomings, the database of surface cover generated by the neural network classifier is a useful representation of the spatial distribution of exposed geological materials in the study area, with an overall agreement with ground truth of $87.7 \%$. In contrast, the fraction images generated through unmixing are poor representations of ground truth for several key lithological classes. These results underscore both the considerable utility and marked limitations of Landsat TM data in the mapping of igneous and metamorphic lithologies.
\end{abstract}

Keywords: geology; reflectance; neural network; deconvolution; Thematic Mapper 


\section{Introduction}

Maps of bedrock geology provide information regarding the spatial distribution of lithological units at and near the Earth's surface, but are typically not precise sources of information regarding the surface distribution of exposed geological materials. Remote sensing techniques increasingly offer a means for the successful discrimination and mapping of exposed rock classes and associated weathering products, providing information that is complementary to that of maps of bedrock geology. Opportunities for the application of remote sensing techniques in the mapping of surface geology are especially prevalent for arctic and arid regions where vegetation cover is sparse. Generated digital databases of surface lithology can be used to support activities including geological mapping, mineral exploration, and environmental characterization.

The trend in remote sensing instrumentation is toward improvements in spectral and spatial resolutions, with hyperspectral systems and associated processing techniques offering some of the greatest potential for near-term enhancement of remote sensing capacities (e.g., [1,2]). However, the available geographic coverage of images generated by orbiting hyperspectral sensors or advanced multispectral sensors (e.g., Hyperion and ASTER) currently remains limited relative to that of multispectral systems designed to support the long-term monitoring of global surface cover. The Landsat Thematic Mapper (TM) series of instruments, though offering modest spectral coverage compared to hyperspectral systems, has retained a central role in the discrimination and mapping of surface cover [3,4]. TM image archives offer wide geographic and temporal coverage at no cost to users [5], ensuring that TM data will continue to play an important role in the study of the Earth's surface in the near term.

This study involved evaluation of the utility of Landsat TM multispectral data in the characterization of surface geology in the central part of the Cape Smith Belt of northern Quebec, an Early Proterozoic greenstone belt of considerable scientific and economic interest. The north-central part of the belt is composed of Watts Group mafics and ultramafics, which together comprise the remnants of two-billion-year-old ( $2 \mathrm{Ga}$ ) obducted oceanic crust (the Purtuniq ophiolite). This study sought to (1) characterize the reflectance properties of geological materials in the study area; and (2) determine the utility of Landsat TM data in the discrimination of lithological classes using a per-pixel feedforward backpropagation neural network classifier and a linear unmixing algorithm.

\section{Discrimination of Rock Types Using Multispectral Remote Sensing Data}

The reflectance characteristics of individual lithological classes (i.e., rock or soil types) are primarily a function of the presence and relative proportions of component minerals. The ease with which lithologies can be discriminated for a given study area is determined by the relative distinctiveness of the reflectance spectra of individual classes. For the reflectance spectra of individual minerals, absorption features that fall within the range of $\sim 0.4$ to $1.0 \mu \mathrm{m}$ are mainly associated with electronic transitions caused by the presence of transition metals (e.g., Ti, $\mathrm{Fe}, \mathrm{Mn}, \mathrm{Cu}, \mathrm{Ni}, \mathrm{Cr}$ ), whereas absorption features in the range of $\sim 1$ to $3 \mu \mathrm{m}$ are predominantly associated with vibrational transitions caused by the presence of common anionic constituents such as carbonates, hydroxyls, and phosphates [6,7]. In practice, the greatest potential for the discrimination of lithological classes using reflected solar 
radiation is within the range between $\sim 0.7$ and $3 \mu \mathrm{m}$, where variation between reflectance spectra is typically greatest (e.g., [8,9]).

The reflectance properties of rocks are largely constrained by the physical and chemical nature of the upper several hundred micrometers of rock or grain surfaces. Thus, where chemical weathering has been significant, the reflectance spectra of geological materials can be controlled by surface alteration rinds rather than by the fresh internal mineralogies that otherwise define material types (e.g., [10]). Spatial variation in the degree and nature of surface weathering, and differences in the nature of vegetative or other cover, can complicate the potential for discrimination of individual lithological classes (e.g., [11,12]).

The spectral characteristics of Landsat TM images remain superior to those of most orbiting multispectral systems [3]. Landsat TM images have been used with mixed success to map igneous and metamorphic units (e.g., [11,13-17]), as well as clastic, carbonate, and evaporitic lithologies (e.g., [18-22]). TM data have been applied with some success in the mapping of prominent zones of mineral alteration such as those marked by the presence of abundant oxides and hydroxides (e.g., $[23,24]$ ). In general, because the potential for discrimination of lithologies is greatest in the near- and mid-infrared ranges of the spectrum, TM bands $3(0.63-0.69 \mu \mathrm{m}), 4(0.76-0.90 \mu \mathrm{m}), 5$ $(1.55-1.75 \mu \mathrm{m})$, and $7(2.080-2.35 \mu \mathrm{m})$ have proven to be especially useful in past geological work (e.g., $[17,25,26])$.

TM-based lithological discrimination efforts have had mixed success for ophiolitic and associated units. Several groups $[17,27,28]$ have used TM bands 4,5 , and 7 to successfully discriminate between major ultramafic (serpentinized harzburguite with dunite) and mafic classes (including deeper gabbroic intrusives, shallower diabase intrusives, and basaltic extrusives) at the Semail ophiolite in Oman, though important ambiguities were associated with some hydrothermally altered zones. TM data were successfully used to discriminate lithological classes of the Betsimisaraka suture of Madagascar, including granite, gabbro, and gneiss [29]. Serpentinites, granites, mafic and intermediate volcanics, and marbles were properly discriminated at the Atmur-Delgo suture of Sudan [30], and TM data were used to separate serpentinized units from metavolcanics in the adjacent Barramiya area of Egypt [31]. TM data were used to generate mineralogical information for the Troodos ophiolite in Cyprus, though the relatively low spectral resolution of TM data weakened the utility of fraction images generated through unmixing procedures, allowing for the definition of no more than five end members and inhibiting the generation of fraction images with consistently good correspondence with ground truth [32,33].

\section{Study Area}

\subsection{Overview and Surface Classes}

The Cape Smith Belt of northern Quebec is an Early Proterozoic greenstone belt that forms part of the Quebec-Baffin segment of the Trans-Hudson Orogen [34-38] (Figure 1). The Cape Smith Belt mainly consists of east-west trending mafic-ultramafic thrust sheets and was produced by southward-directed thrusting of allochthonous crust onto the Superior Province [39]. There are five distinct Early Proterozoic suites associated with the belt [38,40,41]: (1) fluvio-deltaic sediments of the Povungnituk Group (preserved south of the belt on unstretched continental crust of the Superior Province); (2) rift-fill 
sediments of the Povungnituk Group; (3) transitional crust basalts (pillowed and massive basalt flows) of the Chukotat Group; (4) deep-water sediments (pelites interbedded with minor sandstone) of the Spartan Group; and (5) basalts, sheeted dikes, and mafic-ultramafic plutons of the Purtuniq ophiolite (Watts Group). The northern half of the belt is sparsely intruded by granitoid plutons [39]. Rocks of the Cape Smith Belt have been metamorphosed to between greenschist and amphibolite facies [37,42]. Common metamorphic equivalents in the region include schists (produced from original pelite and semipelite), greenschists (produced from original basalt and gabbro), and partly serpentinized ultramafics (produced from original peridotite). Peridotite bodies in the region host nickel-copper sulfide deposits rich in platinum-group elements, and these deposits are the primary focus of ongoing mining operations in the region [43].

Figure 1. Simplified geological map of the Cape Smith Belt, northern Quebec, Canada (after [34,35]). The location of the study area is indicated.

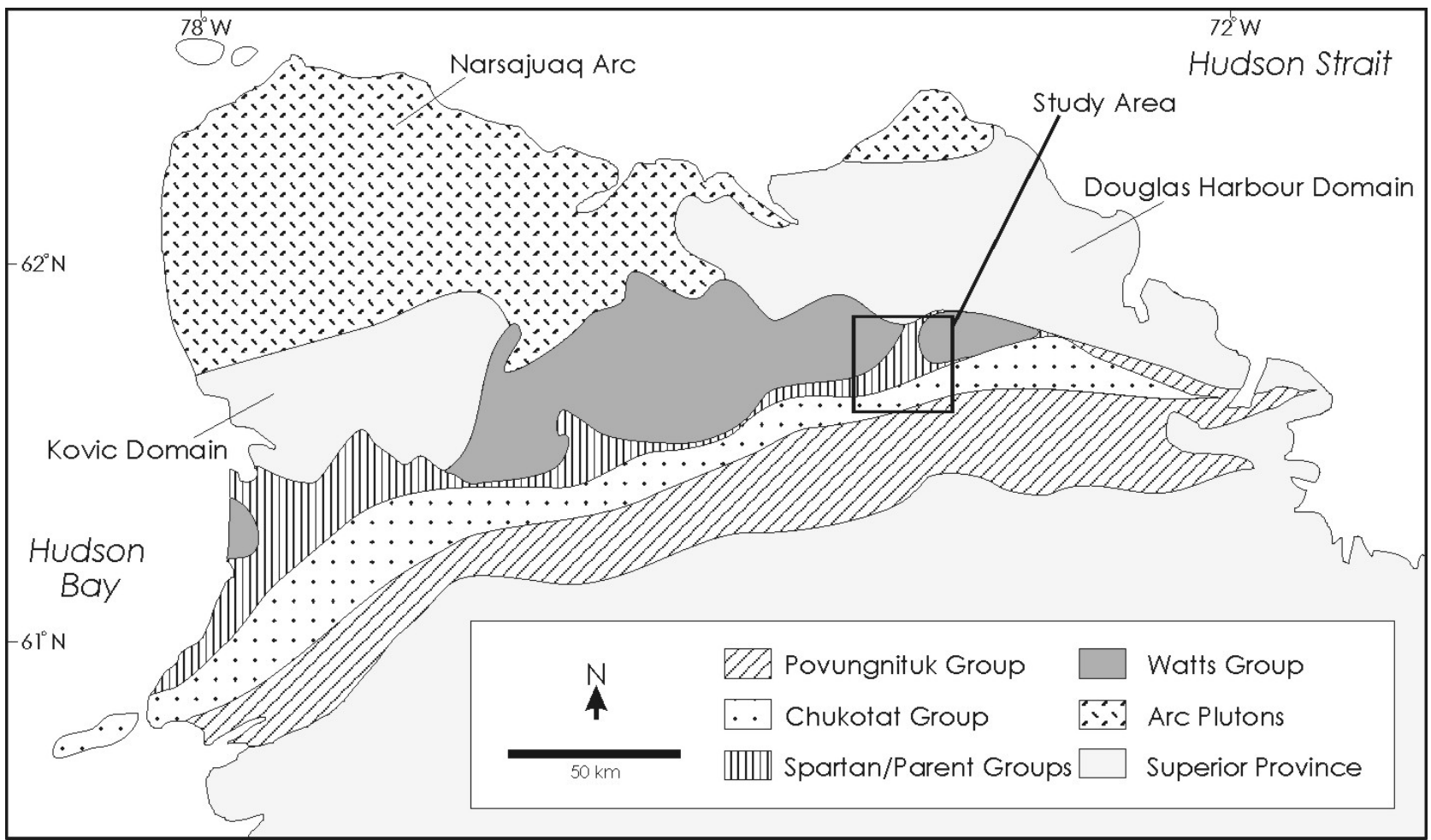

The study area is 28 by $31 \mathrm{~km}$ and is located in the north-central part of the Cape Smith Belt (Figures 2 and 3). This study area was chosen for its excellent exposure of meta-igneous lithologies typical of the Watts and Chukotat groups. Bedrock exposures in the study area are dominated by: (1) basalt, gabbro, and peridotite of the Watts Group (Purtuniq ophiolite); (2) pelite (generally fine clastic sediments) of the Spartan Group (and locally of the Povungnituk Group in the south); and (3) basalt of the Chukotat Group (Figures 4 to 7; Table 1). Local exposures of tonalite and other gabbro and peridotite bodies are also distributed across the region. Exposure of bedrock and associated frost-shattered felsenmeer is generally very good in the region. Elevations in the study area range from $\sim 100$ to $600 \mathrm{~m}$ above sea level, and prominent hills are generally associated with igneous units. 
Figure 2. Bedrock geology of the study area (after [36]). Water bodies are depicted in white. The large water body in the northwestern part of the study area is Lac Watts. The locations of field sites depicted in Figures 4 to 7 are given.

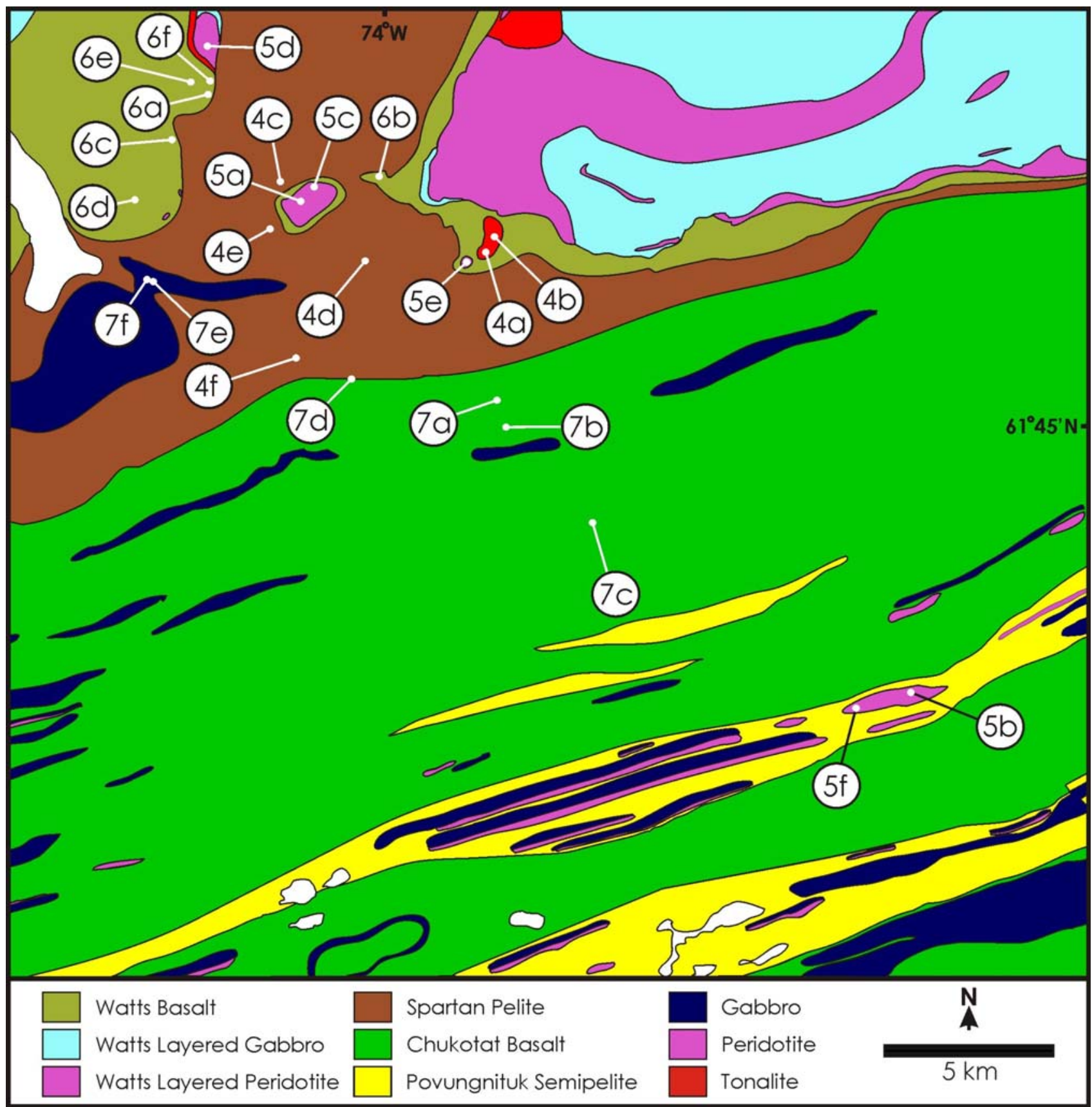

Vegetation in the study area is mainly characterized by barrens communities, including mosses and grasses. Biological cover is generally sparse on tonalite, peridotite, and Chukotat Group basalt units, and on these units is limited mainly to lichens and scattered heather (Cassiope tetragona) and moss (mainly Rhacomitrium lanuginosum). The extent of cover is variable on Watts Group basalt and gabbro units, with cover mainly consisting of heather, moss, and grass. Vegetation cover is nearly complete on pelite units of the Spartan Group, and consists mainly of moss and grass. The extent of lichen cover in the study area is variable and includes the varieties Orphniospora moriopsis, Stereocaulon arenarium, Allantoparmelia alpicola, Rhizocarpon geographicum, Lecidella sp., Aspicilia sp., and Pertusaria sp. [44]. 
Past optical remote sensing work in the Cape Smith Belt has included evaluation of Landsat TM data for generation of fraction images of mafic and ultramafic lithologies in the southern part of the belt [45]. In that work, aerial radar data were found to be helpful in identifying blocky outcrops in the region, and fusion of TM and radar data was found to be useful in the discrimination of peridotite and mafic classes. Much recent work in the region has focused on the potential applicability of hyperspectral datasets toward geological mapping and mineral exploration. For example, unmixing of Probe-1 aerial hyperspectral data was performed in the Povungnituk Range in the southern part of the region, where some success in the identification of mafic rock types was attained despite complications related to factors such as lichen cover [46]. In a separate study, units associated with the Povungnituk Group and Chukotat Group were also investigated using Probe-1 aerial hyperspectral data, using x-ray diffraction measurements to help interpret image data [47].

Figure 3. Landsat TM color composites of the study area depicted in Figure 2. (a) 321-RGB (true color). (b) 432-RGB (color infrared). (c) 543-RGB. (d) 754-RGB.

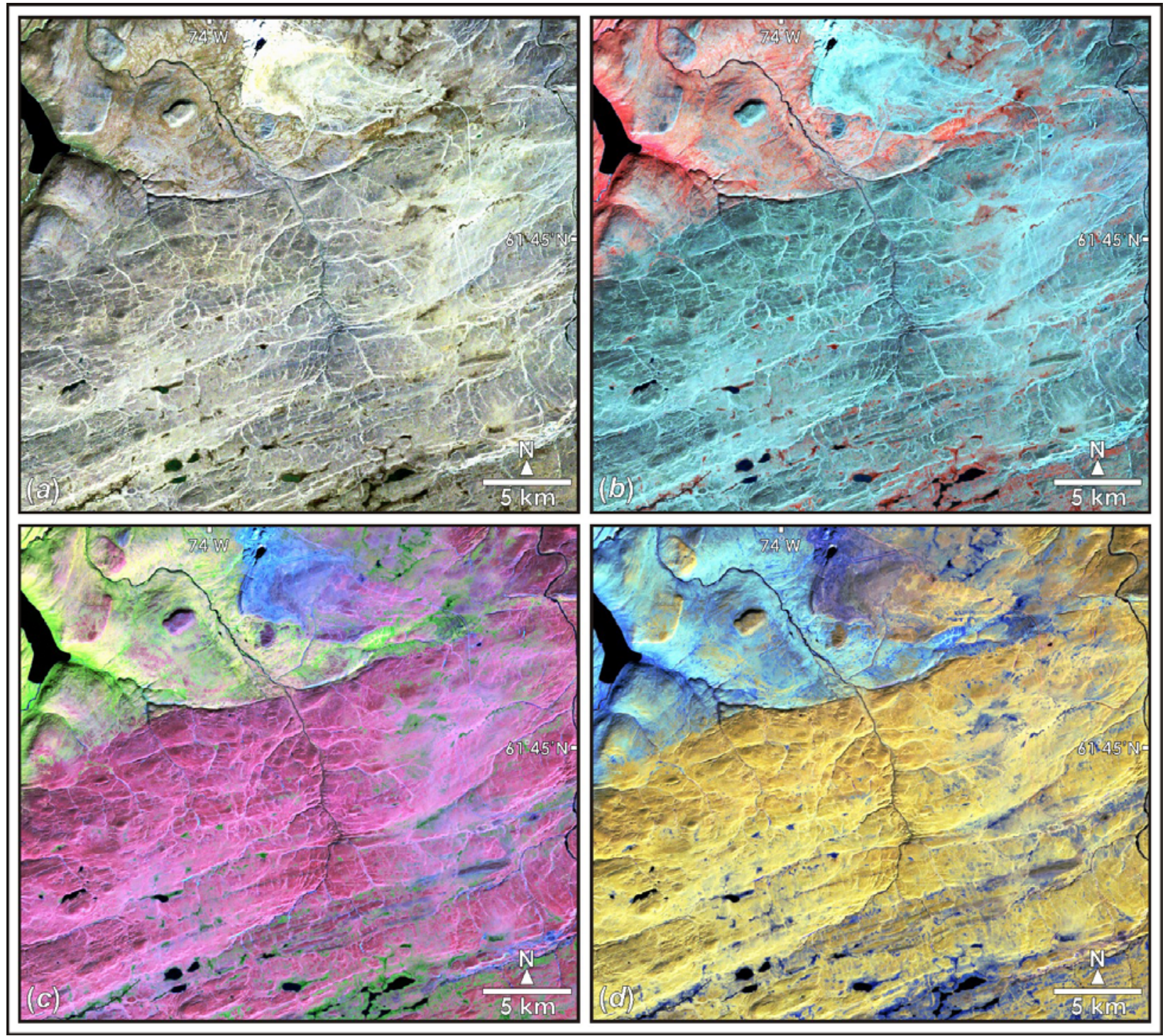


Figure 4. $(\mathbf{a}, \mathbf{b})$ Tonalite is well exposed only in the north-central part of the study area, where outcrops form a single topographic high. (c,d) Prominent exposures of pelite bedrock and associated felsenmeer are relatively rare in the study area. (e,f) Most pelitic materials are found at lower elevations in the study area and are typically extensively covered by grass where slopes are low. Site locations are given in Figure 2.

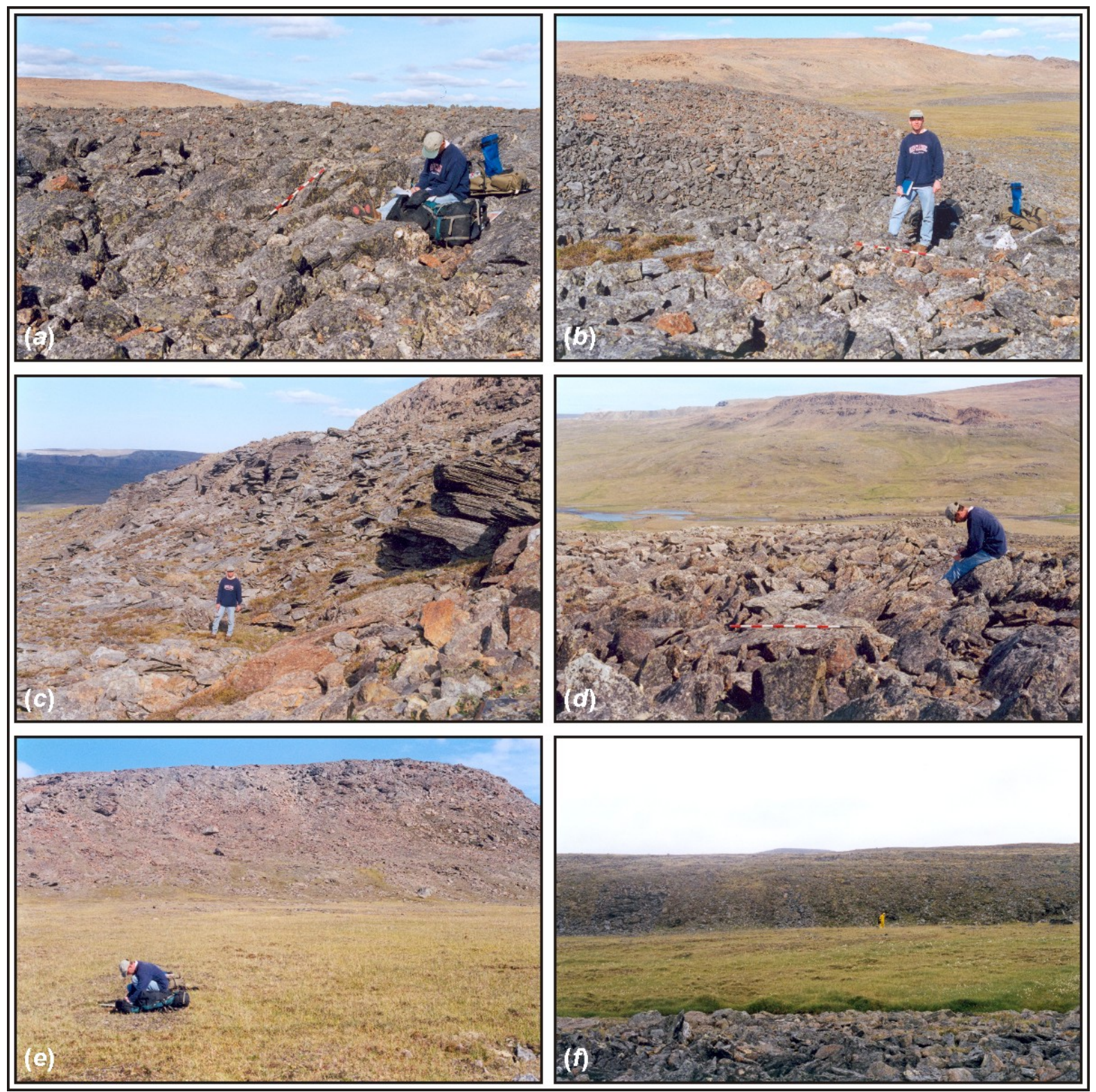

\subsection{Rock Classes and Reflectance Properties}

The key lithological classes in the study area are tonalite, pelite, peridotite, Watts Group mafics, and Chukotat Group mafics, all of which have been metamorphosed to greenschist and amphibolite facies. Of these classes, only pelitic materials are widely covered by green vegetation in the study area. Though the surfaces of most rock units in the region are partly covered by lichen (e.g., $[44,46]$ ), exposure of bedrock and associated felsenmeer is generally excellent in the study area. 
Figure 5. Peridotite units generally form distinct topographic features in the study area. Though fresh peridotite surfaces are mainly green to dark gray in the study area, exposed surfaces generally weather to orange or brown. (a-e) Ground views of prominent exposures of peridotite. (f) Low-elevation aerial view of a 3-km-long peridotite mound exposed in the southeastern part of the study area. Site locations are given in Figure 2.
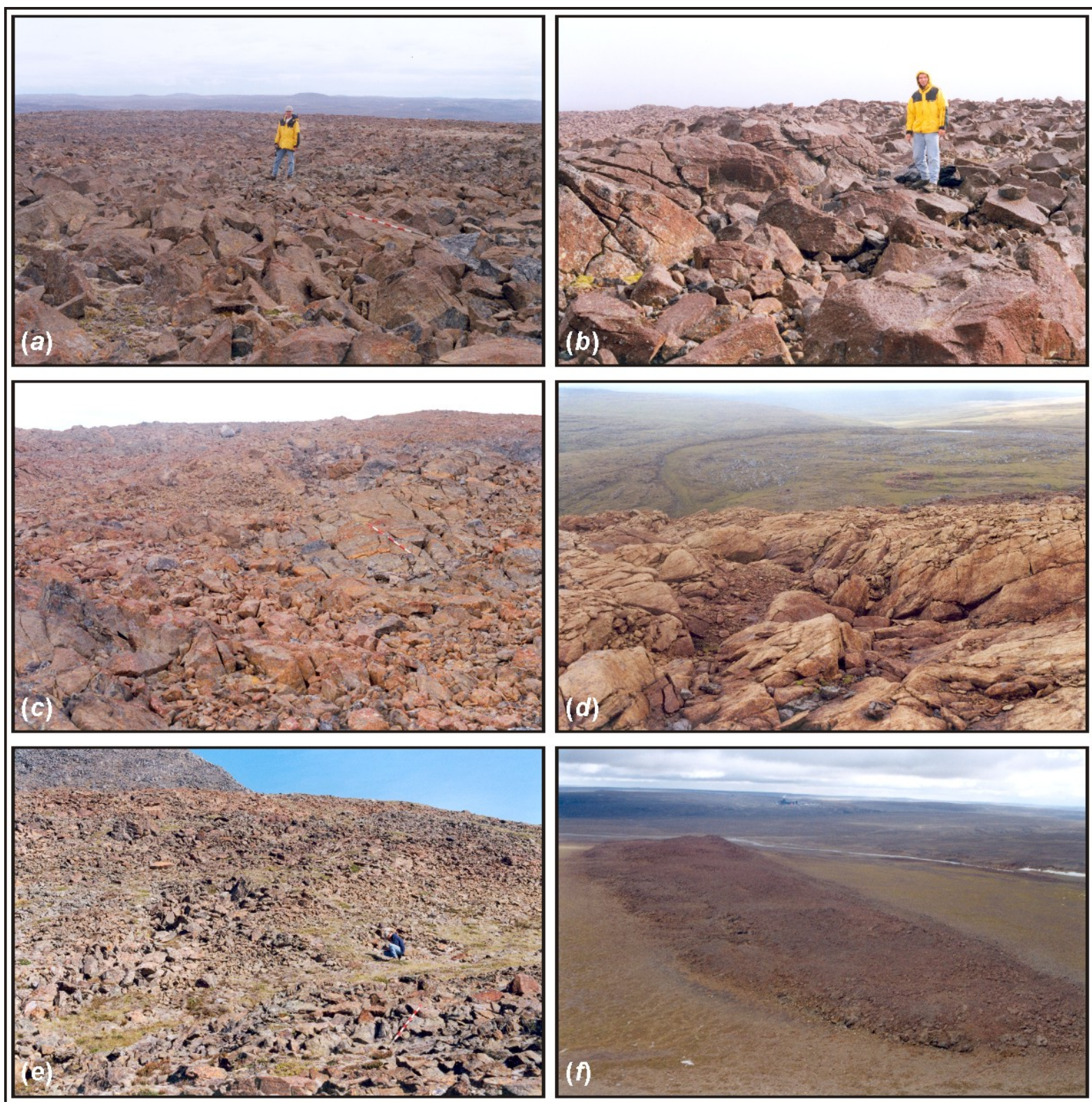

The mineralogies of rock units in the study area were determined from field samples through petrologic characterization of associated thin sections. Rock compositions are consistent with those expected of parent igneous and sedimentary materials subjected to medium- to high-grade metamorphism. Tonalites in the study area are predominantly composed of quartz, plagioclass feldspar, and epidote, as well as minor sericite and chlorite. Pelites are mainly composed of quartz, plagioclase feldspar, and chlorite, with muscovite and calcite also being common constituents. Peridotites in the study area are largely composed of augite, serpentine, chlorite, epidote, and olivine. Watts Group mafics are predominantly composed of actinolite, epidote, and minor albite and calcite, whereas Chukotat Group mafics are composed of plagioclase feldspar, actinolite, epidote, and chlorite. 
Figure 6. (a-f) Though covered in places by grasses, the basalts and gabbros of the Watts Group are generally well exposed in the study area. These units comprise the upper parts of the Purtuniq ophiolite, and variously include pillow basalts, sheeted dikes, and plutons. Site locations are given in Figure 2.

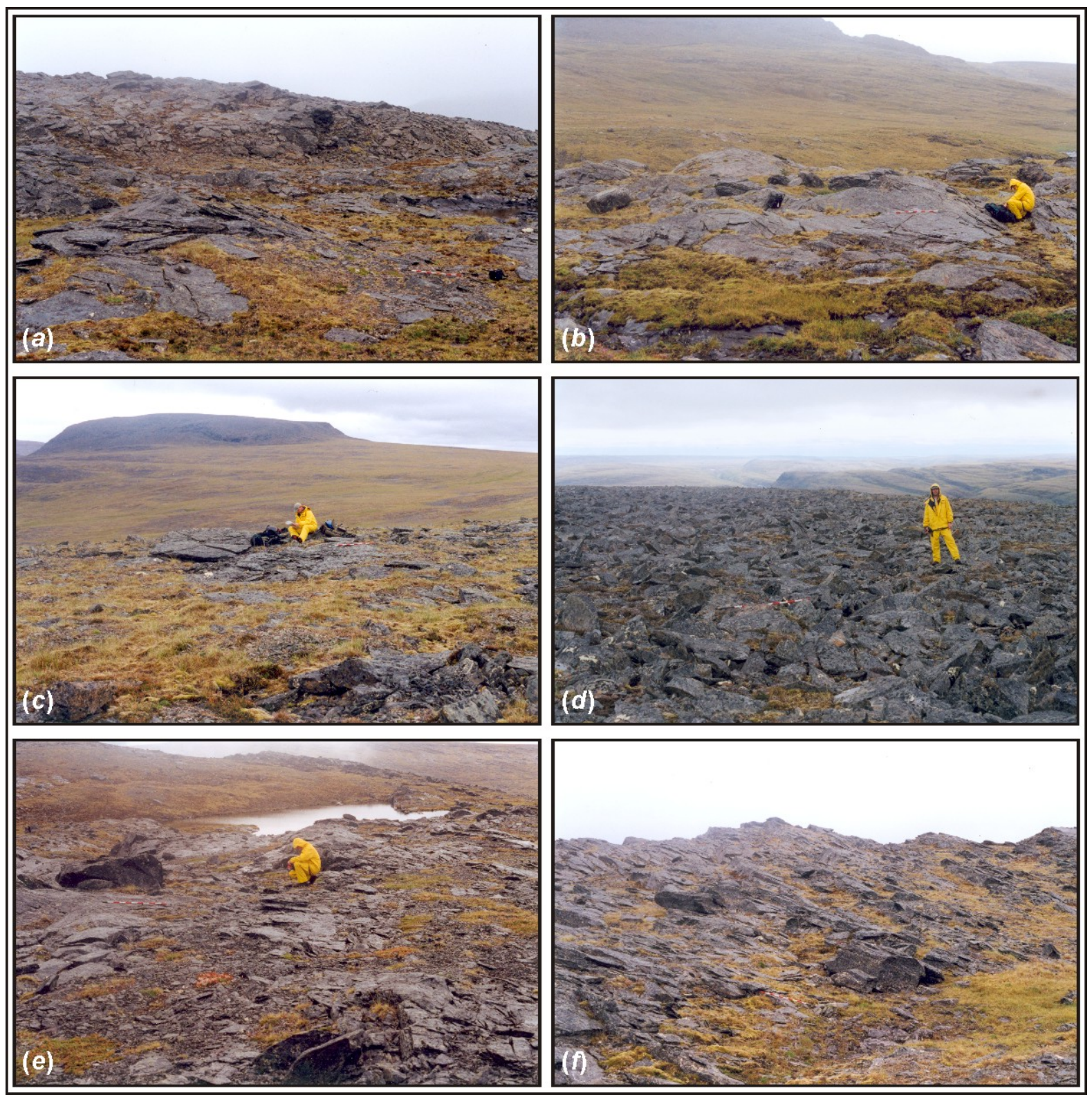

The reflectance properties of lithological classes in the study area are summarized in Figures 8 and 9 for both fresh and weathered surfaces. Spectra were collected for representative field samples using an Analytical Spectral Devices FieldSpec3 spectroradiometer equipped with a contact probe. The spectra of weathered surfaces are similar to those of corresponding fresh surfaces for tonalite, pelite, and Watts Group mafic units. In contrast, the weathered spectra of the peridotite and Chukotat Group mafic units are distinct from associated fresh spectra, and indicate the presence of oxides and hydroxides formed through aqueous alteration (e.g., absorption features suggest the presence of alteration minerals including hematite, goethite, and serpentine); these results are consistent with those previously reported for study areas in the southern part of the Cape Smith Belt [45,47]. The distinct weathering characteristics of the peridotite and Chukotat mafic units offer enhanced potential for their 
discrimination from other lithological classes using remote sensing data, though similarities between some weathered surfaces of these particular two units also have the potential to complicate their spectral separation. The spectra typical of weathered tonalite surfaces and weathered pelite surfaces are also similar in nature, with both characterized by relatively low reflectance and an absence of prominent peaks or troughs.

Figure 7. (a-c) Basalts of the Chukotat Group are well exposed in the study area. Exposed surfaces generally weather to orange or brown. (d) A sharp structural boundary exists between pelites of the Spartan Group (left) and pillowed basalts of the Chukotat Group (right). (e-f) Vegetative cover is especially widespread at pelitic and gabbroic units located immediately southeast of Lac Watts. Site locations are given in Figure 2.

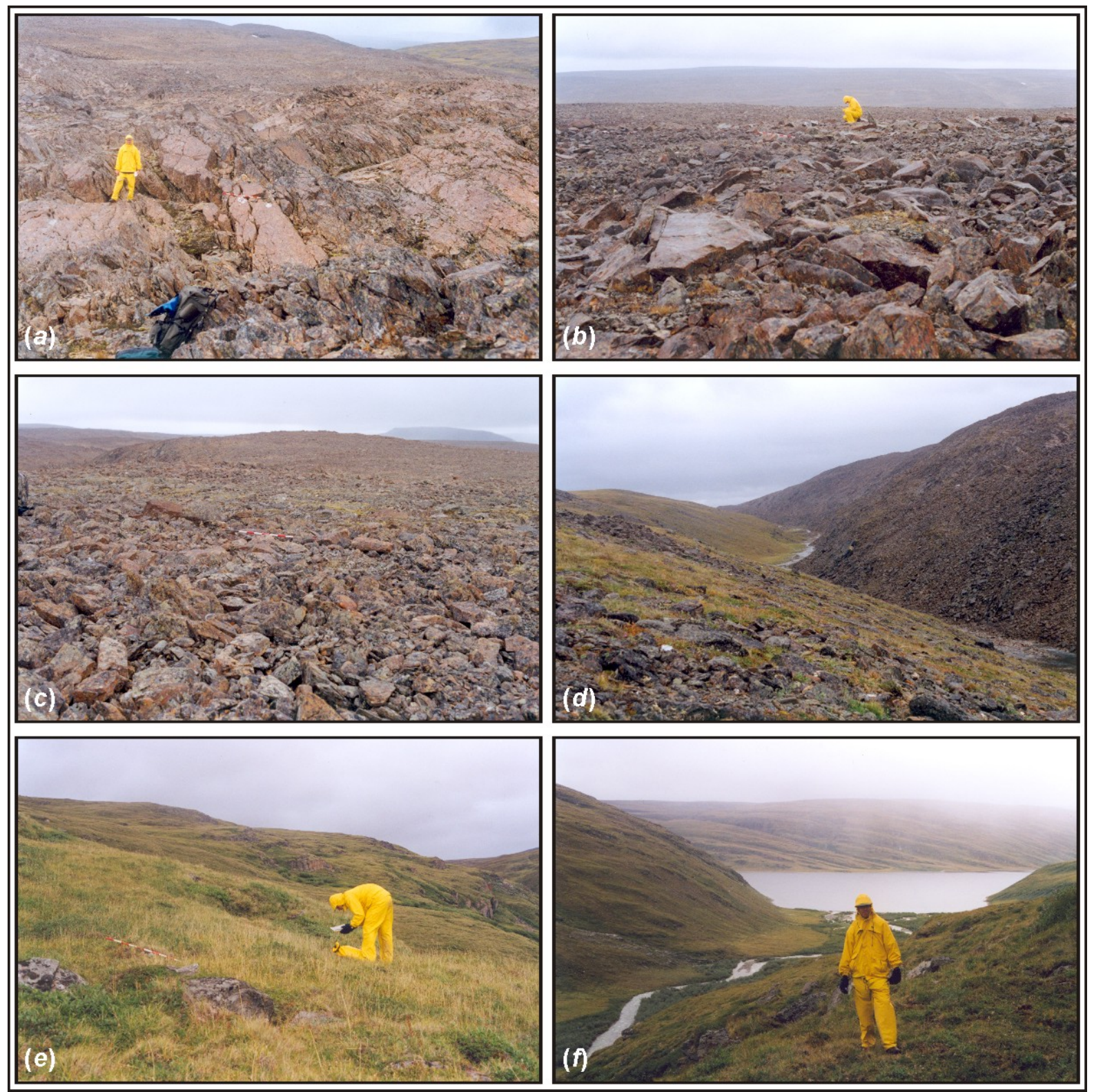

The reflectance properties typical of lichen surfaces in the study area are given in Figure 9 and are consistent with those previously reported for similar varieties (e.g., [48]). Separate lichen classes were not defined in this study, due to its focus on (1) per-pixel classification of multispectral data for a study 
area that lacks lichen dominance at pixel scales of $30 \times 30 \mathrm{~m}$; and (2) unmixing procedures involving multispectral data lacking sufficient spectral resolution for definition and confident discrimination of secondary classes.

Table 1. Lithological classes of the central Cape Smith Belt region (after [38]). All classes have been metamorphosed to between greenschist and amphibolite facies.

\begin{tabular}{|c|c|}
\hline Lithological Class & Description and Interpretation \\
\hline Watts Group mafics & $\begin{array}{l}\text { Pillowed and massive basalt and gabbro; interpreted as mafic volcanics and } \\
\text { sheeted dikes of the } 2.0 \mathrm{Ga} \text { Purtuniq ophiolite. }\end{array}$ \\
\hline Watts Group peridotite & $\begin{array}{l}\text { Layered peridotite; interpreted as ultramafic cumulates of the } 2.0 \mathrm{Ga} \\
\text { Purtuniq ophiolite. }\end{array}$ \\
\hline Chukotat Group mafics & $\begin{array}{l}\text { Pillow basalts and minor gabbro; interpreted as transitional crust formed in } \\
\text { a submarine environment between } \sim 2.04 \text { and } 1.92 \mathrm{Ga} \text {. }\end{array}$ \\
\hline Spartan Group pelite & $\begin{array}{l}\text { Graphitic pelite, semipelite, and minor sandstone; interpreted as deep water } \\
\text { pelagic deposits. }\end{array}$ \\
\hline Povungnituk semipelite & $\begin{array}{l}\text { Semipelite, pelite, sandstone, conglomerate, ironstone, dolomite, minor } \\
\text { mafics and peridotite; interpreted as rift-fill deposits formed between } \sim 2.04 \\
\text { and } 1.92 \mathrm{Ga} \text {. }\end{array}$ \\
\hline Tonalite & Tonalite; interpreted as intrusions that developed between $\sim 2.0-1.8 \mathrm{Ga}$. \\
\hline Other peridotite + gabbro & Peridotite and gabbro; Interpreted as mafic and ultramafic cumulates. \\
\hline
\end{tabular}

\section{Landsat TM Data}

The Thematic Mapper (TM) image used in this study was acquired by Landsat- 5 on 3 September 1997 (Figure 3). Original image values from four image bands (TM bands 3, 4, 5, and 7) were scaled to the range $0.0-1.0$ for use as input to neural-network classifications conducted in this study. The data of all six short-wave TM bands were also converted to measures of reflectance using the ENVIFLAASH implementation of the MODTRAN-4 radiative transfer algorithm [49], permitting the use of independent ground-based reflectance spectra in the unmixing of these data.

\section{Classification and Unmixing Methods}

In this study, TM data were classified using a custom implementation of a standard per-pixel neural-network algorithm, and unmixing procedures were conducted using the ENVI implementation of a standard linear deconvolution algorithm. Classification of the TM image was performed in order to determine the utility of these data and a neural network algorithm for per-pixel separation of major lithological classes associated with the Purtuniq ophiolite. Spectral unmixing was performed to determine the capacity of TM data and a linear algorithm for the meaningful generation of fraction images for key geological end members in the study area. The successful characterization of surface materials using fraction images can allow for the separation at sub-pixel scales of otherwise mixed spectral contributions of geological classes and cover materials such as vegetation. 
Figure 8. Reflectance spectra typical of fresh (left) and exposed (right) surfaces in the study area for (a) tonalite, (b) pelite, and (c) peridotite.
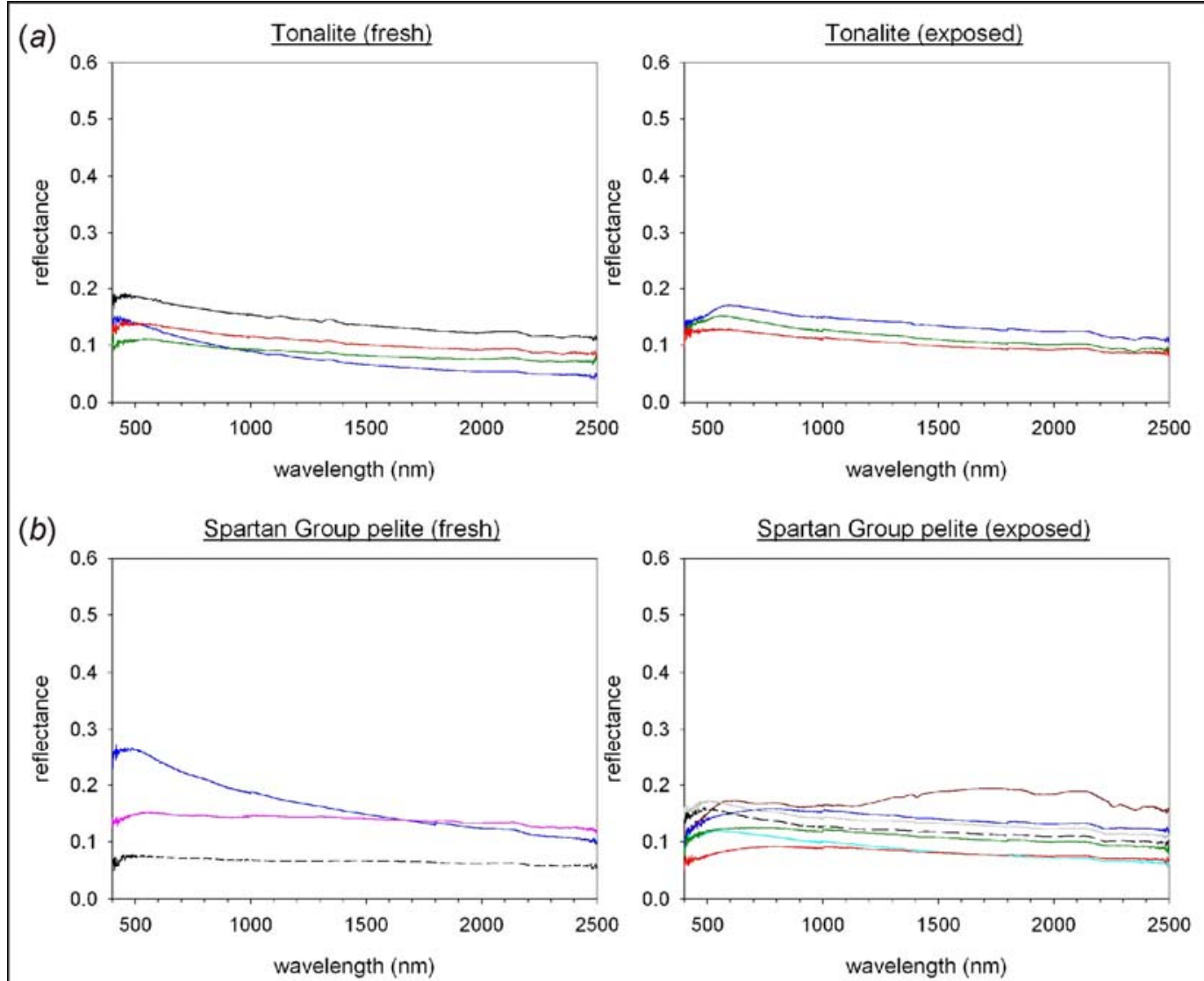

(c)
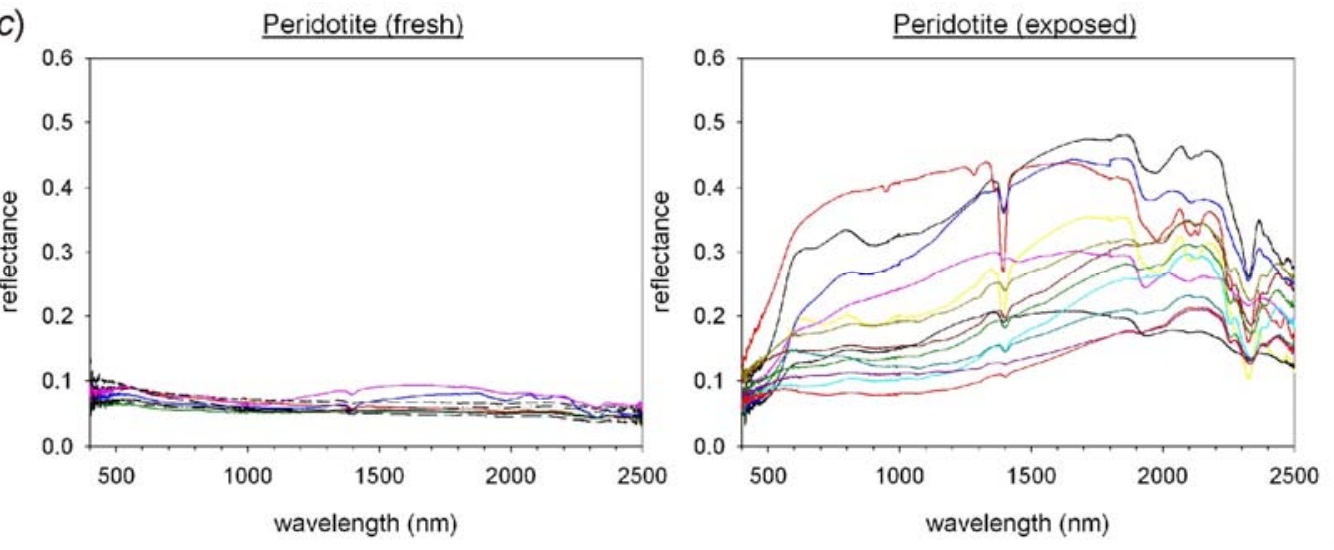

\subsection{Neural Network Classification}

Feedforward backpropagation neural networks are well established as effective algorithms for use in image classification (e.g., [50-52]). Neural networks are especially useful for the mapping of geological materials, since individual geological classes are commonly characterized by substantial variation in reflectance properties as a result of spatial inhomogeneities in mineralogy, degree of chemical alteration, and surface exposure [44,53]. Unlike classifiers such as the maximum likelihood algorithm, neural networks do not require parameterization of training data using simple distribution models, allowing irregular (e.g., multimodal) distributions in training databases to be more properly considered during classification. 
Figure 9. Reflectance spectra typical of fresh (left) and exposed (right) surfaces in the study area for (a) mafics of the Chukotat Group and (b) mafics of the Watts Group. (c) Reflectance properties typical of lichen surfaces.
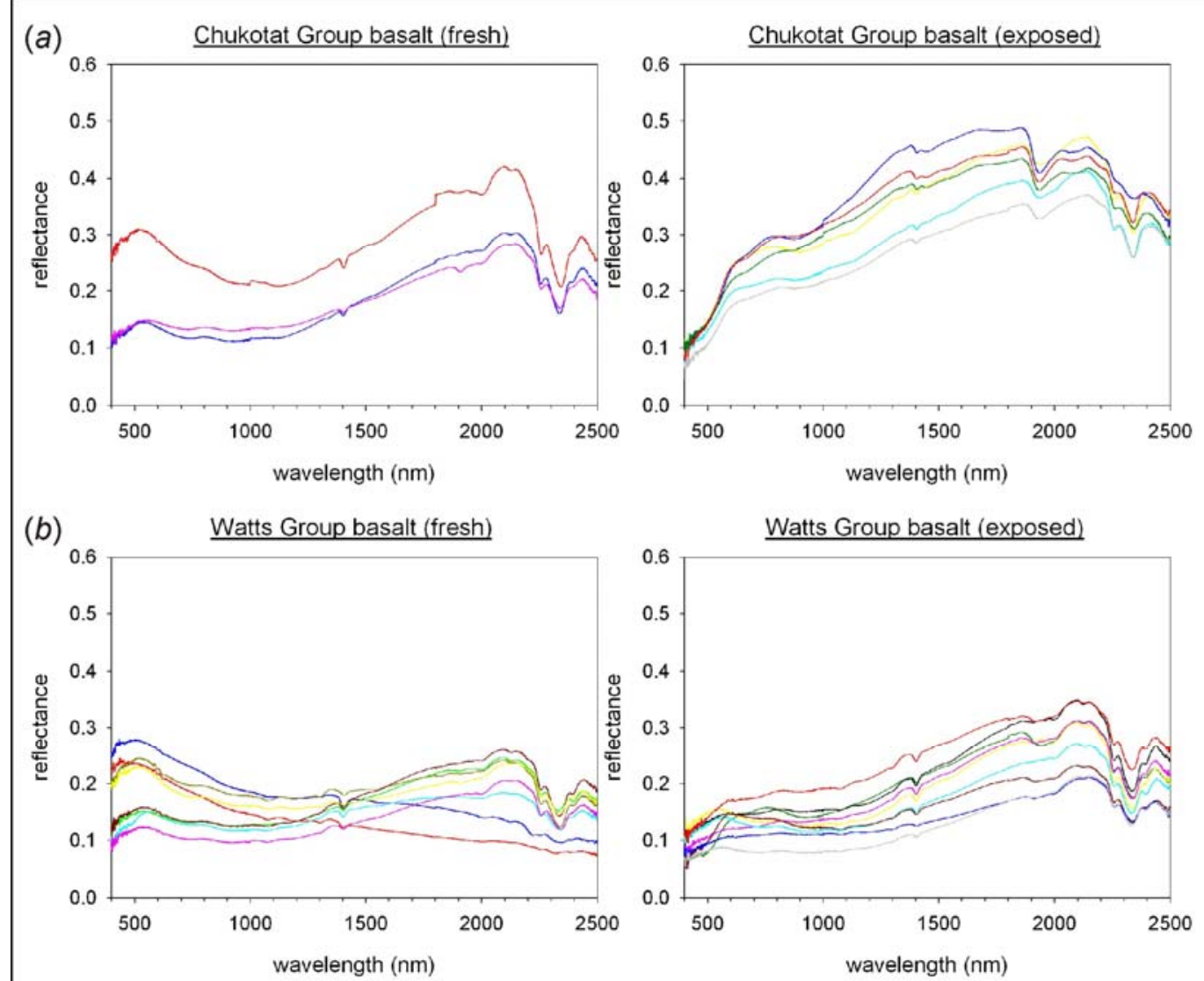

(c)

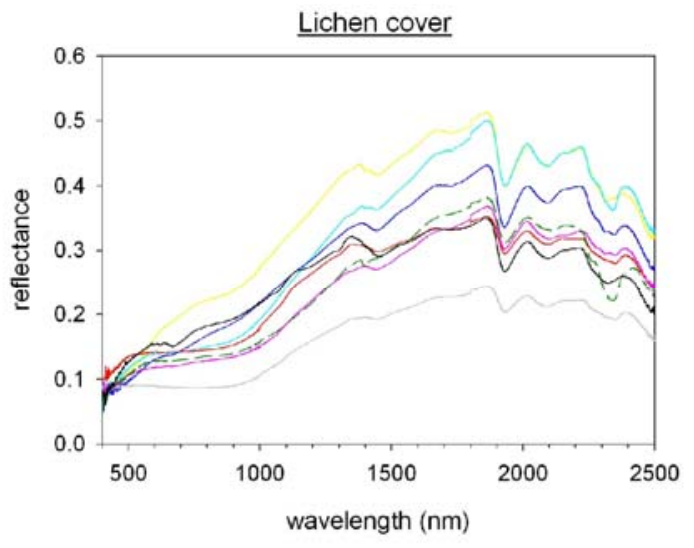

The neural network software used in this study was programmed in $C$ on the basis of established neural network principles (e.g., [54]). The algorithm is a standard feedforward network that utilizes a backpropagation routine to calculate derivatives of training error and to adjust network weights to minimize error. Error is calculated on the basis of the "total sum of squares" (tss) error over all output nodes; the target tss error used in training corresponded to an average error per output node of 0.10 . The sigma nonlinearity in [0.0,1.0] is used as the activation function for all hidden and output nodes [55]. For this study, settings for the learning rate and momentum [55] were 0.1 and 0.9 , respectively. Initial weights were individually set at random within a possible range of -0.5 to +0.5 . Each node of the output layer was assigned to a unique class, and class labels were assigned on the basis of activation 
values (for a given pixel classification, the class associated with the highest node value is that which is assigned as a label). During initial training, target activations for "correct" and "incorrect" nodes were set to 0.9 and 0.1 , respectively. Two intermediate layers were used in all executions in order to allow complex relations between image values and surface classes to be determined. On the basis of established neural network principles (e.g., [54,55]), intermediate layers were defined using as many nodes as the maximum of the number of nodes within the input and output layers.

Scaled versions of TM bands 3, 4, 5, and 7 were used as input to the neural network. The seven major surface classes that dominate the surface cover of the study region were used as classification categories: green vegetation, water, peridotite, Chukotat Group mafics, Watts Group mafics, tonalite, and pelite. Ground-truth information gained during field inspection of the study area was used to guide the selection of 300 pixels to represent each class. These pixels were randomly separated into $66 \%$ training and $34 \%$ testing pixels, stratified by class so that each class was defined by 198 training pixels and 102 test pixels. In order to test variability previously seen in the outcomes of preliminary classifications based on much smaller training and test databases [56], 10 separate classifications were performed; neural network classification outcomes can, in certain cases, vary substantially from execution to execution since initial network weights are typically randomly set at the beginning of each classification procedure.

\subsection{Spectral Unmixing}

Linear unmixing of TM-derived reflectance data was conducted in this study using the ENVI [49] implementation of the "Singular Value Decomposition" method [57]. Reflectance spectra representative of major lithological classes and the green vegetation class are given in Figure 10, accompanied by equivalent spectra sampled at the resolution of TM data. The utilized unmixing method allows for the definition of no more than $Z-1$ end members if $Z$ input images are available, and therefore the use of all six non-thermal TM bands allowed for the definition of only five end members. The water and tonalite classes were thus dropped for unmixing procedures, since these classes together account for less than $2 \%$ of the region's surface area. The five utilized end members therefore consisted of green vegetation, peridotite, Chukotat Group mafics, Watts Group mafics, and pelite. For ease of comparison, output fraction images generated in the unmixing procedure were set to zero for all pixel locations associated with water in the neural network classification result.

\section{Neural Network and Unmixing Results}

\subsection{Summary of Neural Network Results}

The database of surface cover generated in the initial neural network classification is given in Figure 11, and a confusion matrix generated through comparison between predicted and known surface cover for 714 test pixels is given in Table 2. Correspondence between the classified database and ground truth is high: the overall agreement measure of the classified database is $0.877(87.7 \%)$ and the associated Kappa statistic is 0.8562 . Sites dominated by vegetation and by open water were well discriminated by the classifier, with $100 \%$ correspondence between predicted and ground truth cover for associated test pixels. Though not represented in the confusion matrix, shadowing associated with 
topographic relief was responsible for an isolated example of confusion between water and lithological classes in the northwestern part of the study area (compare Figures 2 and 11).

Figure 10. Six spectral end members were available for use in the unmixing of TM data for land pixels. Full-resolution end members are given at left and TM spectral equivalents are given at right.

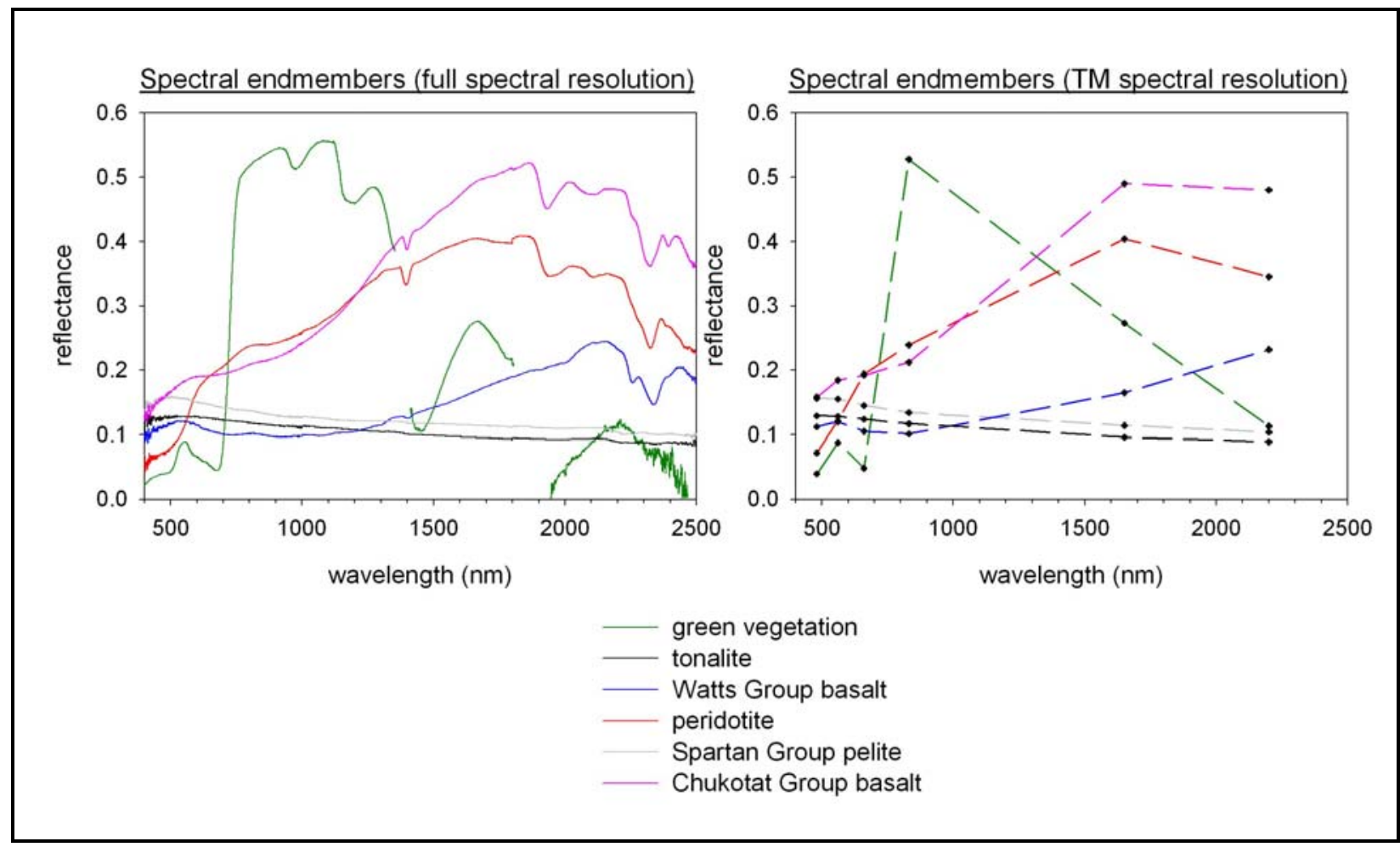

The pelite class was relatively well discriminated in the classified database, with an overall correspondence between predicted and actual ground cover of $92.2 \%$ for test pixels. Confusion between the pelite class and other lithologies was nevertheless prominent in some areas, such as the notable confusion with the Watts Group mafics in the northwestern part of the study area where partial vegetative cover is widespread. The Chukotat Group mafics class was generally well discriminated, with an overall agreement of $86.3 \%$ for test pixels, and with the greatest level of confusion associated with the peridotite and Watts Group mafics classes. The Watts Group mafics class was discriminated with an overall success of $78.4 \%$, with the highest levels of confusion associated with the Chukotat Group mafics class. The tonalite class was discriminated with an overall success of $79.4 \%$, with the greatest confusion existing between this class and the peridotite class. The tonalite class was associated by the classifier with infrastructure-related deposits including those associated with dirt roads and mining activities in the eastern part of the region. The peridotite class was discriminated with an overall success of $77.5 \%$, with the greatest level of confusion associated with both the Chukotat Group mafics and tonalite classes. All prominent peridotite exposures in the study area were properly discriminated by the neural network. Anomalous mapped exposures of peridotite along roads in the eastern part of the study area are related to local mining and transportation activities, which are primarily focused on ultramafic units. 
Figure 11. Map of exposed geological classes for the study area, generated by the neural network classification of scaled versions of TM bands 3, 4, 5, and 7 .

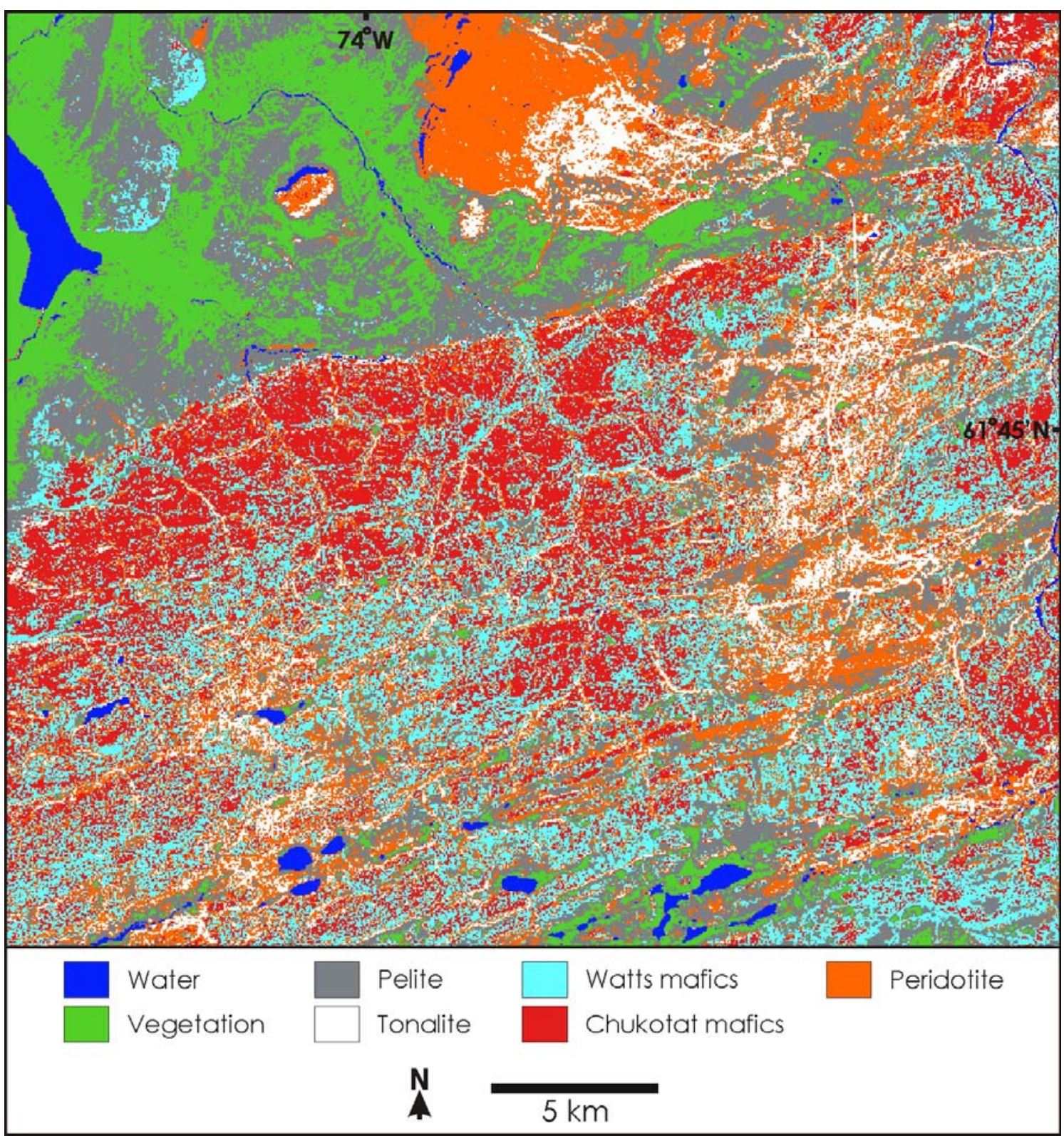

Nine additional neural network classifications were generated using the same training and test datasets (but with different randomly-set initial weight magnitudes), in order to test the consistency of neural network results. The average overall correspondence between predicted classes and ground truth information was $87.26 \%$ for the ten classifications, with a standard deviation of only $\sim 1 \%$. The success of neural network classifications was therefore consistent across all 10 executions, indicating that the high variation typical of the results of preliminary classifications generated for this region using a much smaller training and test database [56] was not reproduced in this study. 
Table 2. Confusion matrix for the neural network classification of Landsat TM data. The overall agreement measure is 0.877 (87.7\%), and the corresponding Kappa value is 0.8562 . Labels for mafic classes are abbreviated: "C-mafic" refers to Chukotat Group mafics and "W-mafic" refers to Watts Group mafics.

\begin{tabular}{|c|c|c|c|c|c|c|c|c|}
\cline { 3 - 9 } \multicolumn{2}{c|}{} & $\mathbf{1}$ & $\mathbf{2}$ & $\mathbf{3}$ & $\mathbf{4}$ & $\mathbf{5}$ & $\mathbf{6}$ & $\mathbf{7}$ \\
\cline { 3 - 9 } \multicolumn{2}{c|}{} & veg & water & peridotite & C-mafic & W-mafic & tonalite & pelite \\
\hline $\mathbf{1}$ & veg & $\mathbf{1 0 0 . 0 \%}$ & & & & & & \\
\hline $\mathbf{2}$ & water & & $\mathbf{1 0 0 . 0 \%}$ & & & & & \\
\hline $\mathbf{3}$ & peridotite & & & $\mathbf{7 7 . 5 \%}$ & $6.9 \%$ & $1.0 \%$ & $19.6 \%$ & $3.9 \%$ \\
\hline $\mathbf{4}$ & C-mafic & & & $6.9 \%$ & $\mathbf{8 6 . 3 \%}$ & $18.6 \%$ & $1.0 \%$ & $1.0 \%$ \\
\hline $\mathbf{5}$ & W-mafic & & & & $6.9 \%$ & $\mathbf{7 8 . 4 \%}$ & & $2.9 \%$ \\
\hline $\mathbf{6}$ & tonalite & & & $9.8 \%$ & & & $\mathbf{7 9 . 4 \%}$ & \\
\hline $\mathbf{7}$ & pelite & & & $5.9 \%$ & & $2.0 \%$ & & $\mathbf{9 2 . 2 \%}$ \\
\hline
\end{tabular}

\begin{tabular}{|c|c|}
\hline Total & Commission \\
\hline $100.0 \%$ & $0.0 \%$ \\
\hline $100.0 \%$ & $0.0 \%$ \\
\hline $108.8 \%$ & $28.8 \%$ \\
\hline $113.7 \%$ & $24.1 \%$ \\
\hline $88.2 \%$ & $11.1 \%$ \\
\hline $89.2 \%$ & $11.0 \%$ \\
\hline $100.0 \%$ & $7.8 \%$ \\
\hline
\end{tabular}

\begin{tabular}{|c|c|c|c|c|c|c|c|c|}
\hline Total & & $100 \%$ & $100 \%$ & $100 \%$ & $100 \%$ & $100 \%$ & $100 \%$ & $100 \%$ \\
\hline Omission & & $0.0 \%$ & $0.0 \%$ & $22.5 \%$ & $13.7 \%$ & $21.6 \%$ & $20.6 \%$ & $7.8 \%$ \\
\hline
\end{tabular}

\begin{tabular}{|l|l|}
\hline & \\
\hline & $12.3 \%$ \\
\hline
\end{tabular}

\subsection{Summary of Unmixing Results}

Fraction images generated through the linear unmixing of reflectance data derived from six TM bands are given in Figure 12 for the green vegetation class and for four lithological classes (peridotite, pelite, Watts Group mafics, and Chukotat Group mafics). The validity of unmixing results is not consistent across all classes.

The green vegetation class is well represented in its corresponding fraction image, with the greatest continuous cover of vegetation properly associated with pelitic and Watts Group mafic bedrock. The fraction image for the green vegetation class also appropriately associates a near absence of vegetative cover with bedrock units composed of Chukotat Group mafics, peridotite, and tonalite. Though some useful geological information can be gained from the unmixing results, none of the four lithological classes is properly represented in the fraction images. Several of the largest and most continuous outcrops of peridotite are properly associated with high (>70\%) predicted surface exposure, but not all outcrops are identified with sufficient prominence (compare the neural network result for peridotite in Figure 11 with the unmixing result in Figure 12), and surface exposure of several percent to several tens of percent is incorrectly predicted for this class over much of the study area. The Chukotat Group mafics class is wrongly predicted to have surface exposure of up to tens of percent over most of the study area, and the broad region of known exposure of Chukotat Group mafics (as appropriately depicted in both Figures 2 and 11) is erroneously not highlighted with elevated estimates of surface exposure (Figure 12). Exposure of the Chukotat Group mafics class is appropriately mapped as low or non-existent at prominent exposures of peridotite, a class with which the Chukotat Group mafics class has some spectral overlap and thus with which it might otherwise be expected to be confused. Exposure of the Watts Group mafics class is properly associated in unmixing results with the less vegetated parts of prominent mafic mounds in the northern part of the study area, but exposure is erroneously predicted for this class at some peridotite mounds and across the main southern region of exposure of the Chukotat Group mafics. Though appropriately delimited in some areas, the pelite class is incorrectly predicted to have its highest surface cover at the large peridotite outcrop in the north- 
central part of the study area, and is also wrongly predicted to have exposure of several percent to several tens of percent across some mafic mounds in the north.

Figure 12. Fraction images generated by the unmixing of TM reflectance data on the basis of five end members. White and black correspond to $70 \%$ and $0 \%$ exposure, respectively. The mapped area is identical to that depicted in Figures 2, 3, and 11.

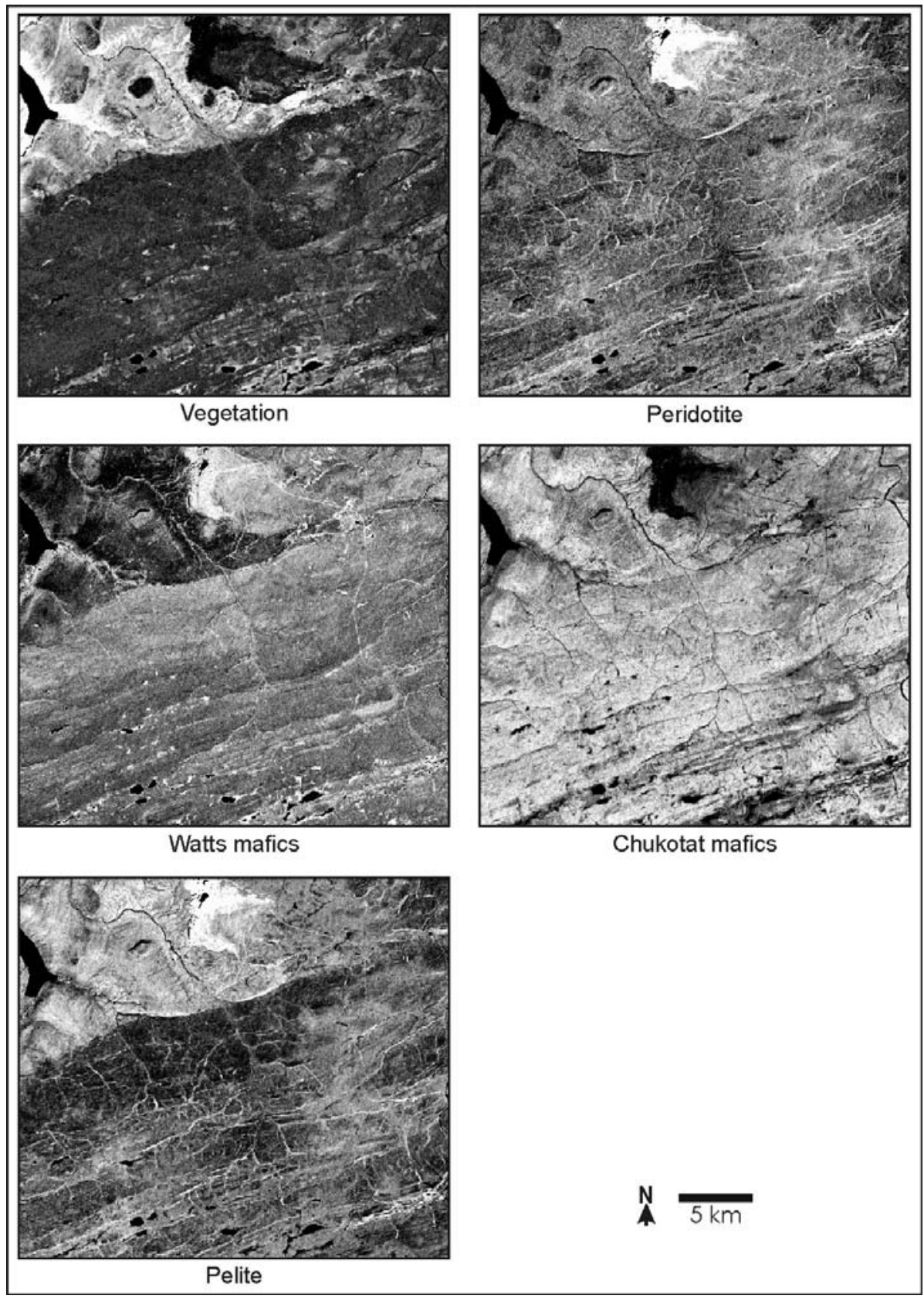

\section{Discussion}

The database of surface cover generated for the study area through neural network classification of TM data (Figure 11) provides surface-cover information that is generally consistent with ground-truth information and complements the information presented in bedrock maps. Class pairs successfully discriminated in the classified database include (1) ultramafics (peridotite) from Chukotat Group mafics; 
and, to a lesser extent, (2) Chukotat Group mafics from Watts Group mafics. Similarly, tonalite and pelite are relatively well discriminated in the database. Unmixing results (Figure 12) generally do not compare favorably with neural network classification results (Figure 11). Though exposure of the green vegetation class was properly delineated in unmixing results, predicted exposure of four key lithological classes was not fully consistent with ground truth. The fraction image for the peridotite class appropriately highlights the general surface distribution of this class, but does not properly depict smaller outcrops of peridotite and incorrectly predicts low to moderate exposure of this class over much of the study area. The fraction images for the Chukotat Group mafics, Watts Group mafics, and pelite suffer from widespread confusion with each other and with the peridotite class.

The results generated in this study underscore both the considerable utility and the marked limitations of Landsat TM data in the mapping of lithological classes in the study area. In particular, per-pixel classification techniques will be of much greater utility than unmixing techniques in the TMbased discrimination of lithological classes with characteristics similar to those of the Purtuniq ophiolite and associated units. Confusion in the classified database between the Chukotat Group mafics and the Watts Group mafics is not a serious issue, as both of these classes are composed of geologically similar materials (basaltic extrusives and gabbroic intrusives). Confusion between the pelite class and the Watts Group mafics is more problematic, but is mainly limited to areas of substantial vegetative cover in the northwestern part of the study area.

Unlike per-pixel classification algorithms, unmixing techniques offer the potential for discrimination of classes at sub-pixel scales. Unmixing procedures can thereby be used to separate the spectral influence of classes that cover surfaces to varying degrees (e.g., vegetation), which has the potential to allow classifiers to better discriminate rock and soil end members. The limited utility of unmixing results in this study suggests a need for improved spectral resolution of input imagery, which can increase the number of allowable end members and can further assist in the spectral separation of lithological classes of interest [32,33].

Beyond consideration of the spectral limitations of TM images, the neural network classification and linear unmixing procedures used in this study may have been undermined by the partial lichen cover of materials exposed in the study region. The complicating effects of lichen are well known for multispectral and hyperspectral work involving northern study regions (e.g., [58-60]), and in unmixing exercises might ideally be best mitigated through the definition of separate lichen end members (e.g., [61]). As noted above, unmixing procedures are also likely to have been further complicated by the spectral diversity of lithological classes in the study area. Whereas the feedforward backpropagation neural network can effectively parameterize variation in the spectral character of training data (e.g., [44]), the unmixing technique essentially assumes spectral homogeneity within individual classes of interest.

\section{Conclusions}

Chemical alteration is a factor that strongly influences the reflectance properties of several lithological classes exposed in the north-central part of the Cape Smith Belt, Quebec, a region partly underlain by materials of the Purtuniq ophiolite. In particular, the reflectance spectra of peridotite and Chukotat Group basalt are largely determined by the materials that comprise associated weathering 
rinds, including oxides and hydroxides. The spectral characterization of individual lithological classes in the study area is complicated by spatial variation in the nature and degree of alteration of mafic and ultramafic materials.

A database of surface cover generated for the study area by a per-pixel neural network classifier is a useful spatial representation of exposed geological materials associated with the Purtuniq ophiolite, and complements the information content of maps of bedrock geology. The overall agreement with ground truth for the neural network classification is $87.7 \%($ Kappa $=0.8562)$, with corresponding class agreements ranging between $\sim 77 \%$ (peridotite) and 100\% (green vegetation and water classes). Errors of omission and commission in the database are as high as $22.5 \%$ and $28.8 \%$, respectively. Despite the good general agreement between predicted and known surface cover, notable confusion exists in the classified database between mafics of the Watts Group and Chukotat Group, and between the pelite class and mafics of the Watts Group. Confusion also exists between the peridotite class and several igneous and sedimentary classes in the study area. The most prominent exposures of ultramafic materials, of special significance in the region because of an association with nickel-copper sulfide deposits, were nevertheless well discriminated by the neural network classifier. In contrast, fraction images generated for the study area through linear unmixing of TM-derived reflectance data are of uneven quality. Whereas the fraction image for the vegetation class is an excellent representation of ground truth, the geological fraction images are generally characterized by widespread confusion between classes.

Shortcomings in the validity of generated fraction images suggest a need for improved spectral resolution of input imagery, which would increase the number of allowable end members and could improve the spectral separation of lithological classes of interest. Differences in the reflectance properties of geological classes can be subtle, and hyperspectral images (acquired over dozens to hundreds of individual wavelength ranges) have the potential to provide the constraints necessary for the successful separation of such classes in unmixing exercises (e.g., [53]). Past studies involving ophiolitic units have suggested that multispectral data can be useful in the general discrimination of igneous and metamorphic lithologies (particularly when working with data acquired in the near- and shortwave-infrared), but have also highlighted the need for improved spectral resolution to support the deconvolution of image or reflectance data. The results of the present study support these findings, and suggest that per-pixel classification techniques will be of greater utility than unmixing techniques in the TM-based discrimination of geological classes with reflectance properties similar to those of classes exposed in the study area. The cloud cover and long winters typical of the north-central Cape Smith Belt have hindered the successful acquisition of advanced multispectral and hyperspectral datasets from orbit (e.g., Hyperion images). Future research will investigate the relative utility of datasets such as these as they become available.

\section{Acknowledgements}

The field campaign at the Purtuniq ophiolite was funded by Northern Scientific Training Program (Canada) and Geological Society of America grants to David Leverington, and by a Natural Sciences and Engineering Research Council (Canada) operating grant to Wooil Moon. Ian Fieldhouse provided assistance in the field, and logistical support was provided by Falconbridge Ltd. 


\section{References}

1. Harris, J.R.; Wickert, L.; Lynds, T.; Behnia, P.; Rainbird, R.; Grunsky, E.; McGregor, R.; Schetselaar, E. Remote predictive mapping 3. Optical remote sensing-A review for remote predictive geological mapping in northern Canada. Geosci. Can. 2011, 38, 49-83.

2. Riaza, A.; Buzzi, J.; Garcia-Meléndez, E.; Carrère, V.; Müller, A. Monitoring the extent of contamination from acid mine drainage in the Iberian Pyrite Belt (SW Spain) using hyperspectral imagery. Remote Sens. 2011, 3, 2166-2186.

3. Goward, S.; Williams, D.; Arvidson, T.; Irons, J. The Future of Landsat-Class Remote Sensing. In Land Remote Sensing and Environmental Change; Ramachandran, B., Justice, C.O., Abrams, M.J., Eds.; Remote Sensing and Digital Image Processing 11, Springer Science and Business Media: Berlin, Germany, 2011; pp. 807-834.

4. Showstack, R. Concerns about Landsat 5 failure. EOS Trans. AGU 2011, 92, 455.

5. Woodcock, C.E.; Allen, A.A.; Anderson, M.; Belward, A.S.; Bindschadler, R.; Cohen, W.B.; Gao, F.; Goward, S.N.; Helder, D.; Helmer, E.; et al. Free access to Landsat imagery. Science 2008, 320, 1011.

6. Burns, R.G. Origin of Electronic Spectra of Minerals in the Visible to Near-Infrared Region. In Remote Geochemical Analysis: Elemental and Mineralogical Composition; Pieters, C.M., Englert, P.A., Eds.; Cambridge University Press: Cambridge, UK, 1993; pp. 3-29.

7. Gaffey, S.J.; McFadden, L.A.; Nash, D.; Pieters, C.M. Ultraviolet, Visible, and Near-Infrared Reflectance Spectroscopy: Laboratory Spectra of Geologic Materials. In Remote Geochemical Analysis: Elemental and Mineralogical Composition; Pieters, C.M., Englert, P.A., Eds.; Cambridge University Press: Cambridge, UK, 1993; pp.43-77.

8. Schetselaar, E.M. A comparative evaluation on the potential of C-band airborne SAR and panchromatic SPOT images for geologic mapping in the Archean Hood River Belt, Bathurst Inlet, Northwest Territories. Can. J. Remote Sens. 1994, 20, 302-316.

9. Galvão, L.S.; Vitorello, Í. Quantitative approach in the spectral reflectance-lithostratigraphy of the Wind River and southern Bighorn basins, Wyoming. Int. J. Remote Sens. 1995, 16, 1617-1631.

10. McSween, H.Y., Jr.; Taylor, G.J.; Wyatt, M.B. Elemental composition of the Martian crust. Science 2009, 324, 736-739.

11. Macias, L.F. Remote sensing of mafic-ultramafic rocks: Examples from Australian Precambrian terranes. AGSO J. Aust. Geol. Geophys. 1995, 16, 163-171.

12. Rowan, L.C.; Mars, J.C.; Simpson, C.J. Lithologic mapping of the Mordor, NT, Australia ultramafic complex by using the Advanced Spaceborne Thermal Emission and Reflection Radiometer (ASTER). Remote Sens. Environ. 2005, 99, 105-126.

13. Glikson, A.Y.; Creasey, J.W. Application of Landsat-5 TM imagery to mapping of the Giles Complex and associated granulites, Tomkinson Ranges, western Musgrave Block, central Australia. AGSO J. Aust. Geol. Geophys. 1995, 16, 173-193.

14. El Rakaiby, M.L. The use of enhanced Landsat-TM image in the characterization of uraniferous granitic rocks in the Central Eastern Desert of Egypt. Int. J. Remote Sens. 1995, 16, 1063-1074.

15. Van der Meer, F.; Van Dijk, P.M.; Westerhof, A.B. Digital classification of the contact metamorphic aureole along the Los Pedroches batholith, south-central Spain, using Landsat Thematic Mapper data. Int. J. Remote Sens. 1995, 16, 1043-1062. 
16. Kavak, K.S. Determination of palaeotectonic and neotectonic features around the Menderes Massif and the Gediz Graben (Western Turkey) using Landsat TM image. Int. J. Remote Sens. 2005, 26, 59-78.

17. Rajendran, S.; al-Khirbash, S.; Pracejus, B.; Nasir, S.; Al-Abri, A.H.; Kusky, T.M.; Ghulam, A. ASTER detection of chromite bearing mineralized zones in Semail Ophiolite Massifs of the northern Oman Mountains: Exploration strategy. Ore Geol. Rev. 2012, 44, 121-135.

18. Peña, S.A.; Abdelsalam, M.G. Orbital remote sensing for geological mapping in southern Tunisia: Implication for oil and gas exploration. J. Afr. Earth Sci. 2006, 44, 203-219.

19. Boettinger, J.L.; Ramsey, R.D.; Bodily, J.M.; Cole, N.J.; Kienast-Brown, S.; Nield, S.J.; Saunders, A.M.; Stum, A.K. Landsat Spectral Data for Digital Soil Mapping. In Digital Soil Mapping with Limited Data; Hartemink, A.E., McBratney, A., de Mendonca-Santos, M.L., Eds.; Springer Science and Business Media: Berlin, Germany, 2008; pp. 193-202.

20. Saadi, N.M.; Watanabe, K. Assessing image processing techniques for geological mapping: a case study in Eljufra, Libya. Geocarto Int. 2009, 24, 241-253.

21. Sadiq, A.; Howari, F. Remote sensing and spectral characteristics of desert sand from Qatar Peninsula, Arabian/Persian Gulf. Remote Sens. 2009, 1, 915-933.

22. Kaczmarek, S.E.; Hicks, M.K.; Fullmer, S.M.; Steffen, K.L.; Bachtel, S.L. Mapping facies distributions on modern carbonate platforms through integration of multispectral Landsat data, statistics-based unsupervised classifications, and surface sediment data. AAPG Bull. 2010, 94, 1581-1606.

23. Carranza, E.J.M.; Hale, M. Mineral imaging with Landsat Thematic Mapper data for hydrothermal alteration mapping in heavily vegetated terrane. Int. J. Remote Sens. 2002, 23, 4827-4852.

24. Tangestani, M.H., Moore, F. Porphyry copper alteration mapping at the Meiduk area, Iran. Int. J. Remote Sens. 2002, 23, 4815-4825.

25. Mickus, K.; Johnson, E. Mapping sedimentary and volcanic units within and surrounding Petrified Forest National Park, Arizona, using Landsat-5 and SPOT panchromatic data. Int. J. Remote Sens. 2001, 22, 1919-1935.

26. Lorenz, H. Integration of Corona and Landsat Thematic Mapper data for bedrock geological studies in the high Arctic. Int. J. Remote Sens. 2004, 25, 5143-5162.

27. Rothery, D.A. Improved discrimination of rock units using Landsat Thematic Mapper imagery of the Oman ophiolite. J. Geol. Soc. London 1987, 144, 587-597.

28. Abrams, M.J.; Rothery, D.A.; Pontual, A. Mapping in the Oman ophiolite using enhanced Landsat Thematic Mapper images. Tectonophysics 1988, 151, 387-401.

29. Raharimahefa, T.; Kusky, T.M. Structural and remote sensing analysis of the Betsimisaraka Suture in northeastern Madagascar. Gondwana Res. 2009, 15, 14-27.

30. Schandelmeier, H.; Wipfler, E.; Küster, D.; Sultan, M.; Becker, R.; Stern, R.J.; Abdelsalam, M.G. Atmur-Delgo suture: A Neoproterozoic oceanic basin extending into the interior of northeast Africa. Geology 1994, 22, 563-566.

31. Gad, S.; Kusky, T. Lithological mapping in the Eastern Desert of Egypt, the Barramiya area, using Landsat thematic mapper (TM). J. Afr. Earth Sci. 2006, 44, 196-202. 
32. Van der Meer, F.D.; Vazquez-Torres, M.; Van Dijk, P.M. Spectral characterization of ophiolite lithologies in the Troodos Ophiolite complex of Cyprus and its potential in prospecting for massive sulphide deposits. Int. J. Remote Sens. 1997, 18, 1245-1257.

33. Van der Meer, F.; de Jong, S.M. Improving the results of spectral unmixing of Landsat Thematic Mapper imagery by enhancing the orthogonality of end-members. Int. J. Remote Sens. 2000, 21, 2781-2797.

34. St-Onge, M.R.; Lucas, S.B.; Scott, D.J.; Wodicka, N. Upper and lower plate juxtaposition, deformation and metamorphism during crustal convergence. Trans-Hudson Orogen (Quebec-Baffin segment), Canada. Precamb. Res. 1999, 93, 27-49.

35. Giovenazzo, D.; Picard, C., Guha, J. Tectonic setting of Ni-Cu-PGE deposits in the central part of the Cape Smith Belt. Geosci. Can. 1989, 16, 134-136.

36. St-Onge, M.R.; Lucas, S.B. Geology, Eastern Portion of the Cape Smith Thrust-Fold Belt, Parts of the Wakeham Bay, Cratere du Nouveau-Québec and Nuvilik Lakes Map Areas, Northern Québec; Maps 1721A to 1735A; 1:50 000 Scale; Geological Survey of Canada: Ottawa, ON, Canada, 1989.

37. St-Onge, M.R.; Lucas, S.B. Evolution of the Cape Smith Belt: Early Proterozoic Continental Underthrusting, Ophiolite Obduction, and Thick-Skinned Folding. In The Early Proterozoic Trans-Hudson Orogen of North America; Lewry, J.F., Stauffer, M.R., Eds.; Special Paper 37; Geological Association of Canada: St. John's, NL, Canada, 1990; pp. 313-351.

38. St-Onge, M.R.; Lucas, S.B. Geology of the Eastern Cape Smith Belt: Parts of the Kangiqsujuaq, Cratère du Nouveau-Québec, and Lacs Nuvilik Map Areas, Québec; Memoir 438; Geological Survey of Canada: Ottawa, ON, Canada, 1993.

39. Hoffman, P.F. Is the Cape Smith Belt (northern Québec) a klippe? Can. J. Earth Sci. 1985, 22, 1361-1369.

40. St-Onge, M.R.; Lucas, S.B.; Scott, D.J.; Bégin, N.J. Evidence for the development of oceanic crust and for continental rifting in the tectonostratigraphy of the Early Proterozoic Cape Smith Belt. Geosci. Can. 1989, 16, 119-122.

41. Scott, D.J.; Helmstaedt, H.; Bickle, M.J. Purtuniq ophiolite, Cape Smith Belt, northern Quebec, Canada: A reconstructed section of early Proterozoic oceanic crust. Geology 1992, 20, 173-176.

42. Bégin, N.J. P-T conditions of metamorphism inferred from the metabasites of the Cape Smith Belt, northern Quebec. Geosci. Can. 1989, 16, 151-154.

43. Lesher, C.M. Ni-Cu-(PGE) deposits in the Raglan area, Cape Smith Belt, New Quebec. In Mineral Deposits of Canada: A Synthesis of Major Deposit-Types, District Metallogeny, the Evolution of Geological Provinces, and Exploration Methods; Goodfellow, W.D., Ed.; Special Publication 5; Mineral Deposits Division; Geological Association of Canada: Ottawa, ON, Canada, 2007; pp. 351-386.

44. Leverington, D.W. Discriminating Lithology in Arctic Environments from Earth Orbit: An Evaluation of Satellite Imagery and Classification Algorithms. Ph.D. Thesis, University of Manitoba, Winnipeg, MB, Canada, 2001.

45. Mustard, J.F. Lithological mapping of gabbro and peridotite sills in the Cape Smith Fold and Thrust Belt with Thematic Mapper and airborne radar data. Can. J. Rem. Sens. 1994, 20, 222-232. 
46. Staenz, K.; Nadeau, C.; Secker, J.; Budkewitsch, P. Spectral Unmixing Applied to Vegetated Environments in the Canadian Arctic for Mineral Mapping. In Proceedings of XIX ISPRS Congress, Amsterdam, The Netherlands, 16-22 July 2000; Volume XXXIII, Part B7, pp. 1464-1471.

47. Wickert, L.M.; Percival, J.B.; Morris, W.A.; Harris, J.R. XRD and Infrared Spectroscopic Validation of Weathering Surfaces from Ultramafic and Mafic Lithologies Examined Using Hyperspectral Imagery, Cross Lake Area, Cape Smith Belt, Northern Quebec, Canada. In Proceedings of 2008 IEEE International Geoscience and Remote Sensing Symposium, Boston, MA, USA, 6-11 July 2008; Volume 3; pp. 362-365.

48. Bechtel, R.; Rivard, B.; Sánchez-Azofeifa, A. Spectral properties of foliose and crustose lichens based on laboratory experiments. Remote Sens. Environ. 2002, 82, 389-396.

49. Exelis: What is ENVI? Excelis Visual Information Solutions: Boulder, CO, USA. Available online: http:// www.exelisvis.com/ProductsServices/ENVI.aspx (accessed on 15 February 2012).

50. Lu, D.; Weng, Q. A survey of image classification methods and techniques for improving classification performance. Int. J. Remote Sens. 2007, 28, 823-870.

51. Chen, C.H.; Ho, P-G.P. Statistical pattern recognition in remote sensing. Patt. Recog. 2008, 41, 2731-2741.

52. Wang, X.; Zhang, M.; Zhu, J.; Geng, S. Spectral prediction of Phytophthora infestans infection on tomatoes using artificial neural network (ANN). Int. J. Remote Sens. 2008, 29, 1693-1706.

53. Leverington, D.W. Discrimination of sedimentary lithologies using Hyperion and Landsat TM data: A case study at Melville Island, Canadian High Arctic. Int. J. Remote Sens. 2010, 31, 233-260.

54. Gallant, S.I. Neural Network Learning and Expert Systems; MIT Press: Cambridge, USA, 1993.

55. Bishop, C.M. Neural Networks for Pattern Recognition; Oxford University Press: New York, NY, USA, 1995.

56. Leverington, D.W.; Moon, W.M. On the use of consensus algorithms to address variability in the results of neural network classifications: Preliminary tests involving two northern study areas. Can. J. Rem. Sens. 2005, 31, 269-273.

57. Boardman, J.W. Inversion of Imaging Spectrometry Data Using Singular Value Decomposition. In Proceedings of the International Geoscience and Remote Sensing Symposium (IGARSS) 1989, Vancouver, BC, Canada, 10-14 July 1989; Volume 4, pp. 2069-2072.

58. Satterwhite, M.B., Henley, J.P., Carney, J.M. Effects of lichens on the reflectance spectra of granitic rock surfaces. Remote Sens. Environ. 1985, 18, 105-112.

59. Rivard, B.; Arvidson, R.E. Utility of imaging spectrometry for lithologic mapping in Greenland. Photogramm. Eng. Remote Sensing 1992, 58, 945-949.

60. Rollin, E.M.; Milton, E.J.; Roche, P. The influence of weathering and lichen cover on the reflectance spectra of granitic rocks. Remote Sens. Environ. 1994, 50, 194-199.

61. Rogge, D.M.; Rivard, B.; Zhang, J.; Sanchez, A.; Harris, J.; Feng, J. Integration of spatial-spectral information for the improved extraction of endmembers. Remote Sens. Environ. 2007, 110, 287-303.

(C) 2012 by the authors; licensee MDPI, Basel, Switzerland. This article is an open access article distributed under the terms and conditions of the Creative Commons Attribution license (http://creativecommons.org/licenses/by/3.0/). 